\title{
Integrational community therapy with elderly people: literature review
}

\begin{abstract}
The aim of this study is to review a literature on the use of Integrated Community Therapy with elderly people. The review was carried out by means of access to the databases MEDLINE, LILACS, BDENF, use the descriptors "complementary therapies", "senior", and "aging", combined with each other and in the market. Five articles in Portuguese, published in the period from 2013 to 2017, were included that met the study objective. The results showed that it is an Integrative Complementary Therapy and a strategy of care for the elderly in the health and social spheres, because it allows sharing spaces, reducing emotional suffering and distress, and providing a social bonding. However, it is necessary to expand the Brazilian studies aimed at the use of community therapy with an elderly population.
\end{abstract}

Volume 3 Issue 2 - 2018

\author{
Edite Lago da Silva Sena,' Luma Costa \\ Pereira Peixoto, ${ }^{2}$ Raíssa Brito Teixeira, ${ }^{3}$ \\ Vanessa Oliveira Cardoso ${ }^{3}$ \\ 'Professor of the Postgraduate Nursing and Health \\ Program,State University of Southwest of Bahia, Brazil \\ ${ }^{2} \mathrm{PhD}$ student at PPGES/UESB, Brazil \\ ${ }^{3}$ Graduates of the Undergraduate Nursing Course of UESB, \\ Brazil
}

Correspondence: Edite Lago da Silva Sena, Professor of the Postgraduate Nursing and Health Program (PPGES) of the State University of Southwest of Bahia (UESB), PhD in Nursing, Brazil, Email editelago@gmail.com

Received: December 01, 2017 | Published: March 05, 2018

\section{Introduction}

Aging is an innate evolution of human beings, resulting from physiological changes that occur in the course of life. The linkage of the aging process entails organic wear, as well as changes in the cultural, social and emotional principles of the subjects. ${ }^{1}$ In this way, the individual becomes more susceptible to illness and, especially, to social isolation, which exposes him to vulnerability, exclusion and the need for therapeutic strategies to promote mental health.

In this context, we perceive Integrative Community Therapy (TCI) as an important tool for health promotion and reinsertion of the elderly, as it allows them to share their anguish, try to re-signify their suffering and broaden their social relations through the interactions that the Therapy wheels provide.

TCI is a therapeutic category that emerged after the decentralization of health care in Brazil, which made it possible to remodel the mental health care sector. It was officially incorporated in 2008 through the National Policy of Integrative and Complementary Practices (PNPIC), and consists of the creation of sharing wheels, where the participants talk about their experiences of life and suffering, seeking reception for the expression of feelings. ${ }^{2}$

The TCI meetings provide the elderly with the recovery of their self-esteem and the strengthening of their autonomy, as well as overcoming everyday conflicts with the sharing of knowledge. ${ }^{3}$ Thus, the study aims to review the literature on the use of Integrative Community Therapy with elderly people

\section{Methodology}

The composition of this review of the integrative literature originated from researches in the scientific databases MEDLINE,
LILACS, BDENF - Nursing, Index Psychology and IBECS, all accessed through the Virtual Health Library (VHL), in November of the year of 2017, based on the following guiding question: what has been discussed in the literature about the use of Integrative Community Therapy with elderly people?

In order to reach the studies used in this production, the following descriptors were registered in the DeCS: "complementary therapies", "elderly", and "aging", combined with each other through the AND operator.

As inclusion criteria, we used the full text filters available free of charge, presented in the Portuguese language, published during the last five years, that is, between the years of 2013 and 2017, besides the exclusion of articles that after reading the abstract, five scientific papers were selected. However, some studies cited by the articles first found were also included in this review, considering the importance and affinity with the present study.

After the selection of the mentioned studies, the material for the elaboration of the interpretative synthesis was carried out, as proposed by the thematic analysis technique. ${ }^{4}$

\section{Results and discussion}

Through the integrative literature review, it was possible to identify a limited number of studies published at the national level involving TCI themes and aging simultaneously.

This study reveals that the rescue of the life trajectories that are shared during the therapy wheels with the elderly stimulate and enable the memory of what has already been overcome, helping to rehabilitate a body of acquired knowledge that makes them aware of a certain situation. ${ }^{4}$ 
It is also recognized that the meetings on the wheels strengthen the mutual support, because in the statements issued at the end of the wheels appear feelings of courage and confidence. And this is one of the pillars of therapy, to stimulate personal empowerment through the socialization of their daily lives. ${ }^{5}$

In addition, in the closing moments of the wheels, the elderly are grateful for the possibility of participation, for the opportunity to listen and for the speaking space, demonstrating the importance of those moments for their lives. ${ }^{6,7}$

\section{Conclusion}

With the results of the study, it was possible to conclude that the TCI is a strategy of care for the elderly not only in the health area, but also in the social sphere, since in the spaces of sharing, they reduce the emotional suffering and the anguish, and they provide the construction of social bonds. However, it is necessary to expand the Brazilian studies aimed at the use of community therapy with the elderly population.

\section{Acknoweledgements}

None.

\section{Conflict of interest}

Authors declare that there are no conflicts of interest.

\section{References}

1. Ciosak SI, Braz E, Costa MFBNA, et al. Senescence and senility: a new paradigm in Primary Health Care. Rev Esc Enferm USP. 2011;45(2):1763-1768.

2. Fereira FMO, Lazarte R, Dias MD. Terapia Comunitária Integrativa uma construção coletiva do conhecimento. João Pessoa/PB: Ed. UFPB. 2013. $344 \mathrm{p}$.

3. Rocha IA, Braga LAV, Tavares LM, et al. A Terapia Comunitária como um novo instrumento de cuidado para saúde mental do idoso. Rev bras enferm. 2009;62(5):687-694.

4. Minayo MCS (org.). Pesquisa social: teoria, método e criatividade. 29th ed. Petrópolis: RJ: Vozes; 2010.

5. Rocha IA, Ferreira FMO. Contribuições da Terapia Comunitária Integrativa sistêmica para a autonomia do idoso frente a situações adversas. $4^{\circ}$ Congresso Internacional de Envelhecimento Humano (CIEH). Anais CIEH. 2015;2(1).

6. Ferreira FMO, Sá ANP, Rocha IA, et al. Alcoolismo no contexto familiar: estratégias de enfrentamento das idosas usuárias da Terapia Comunitária. Rev Rene. 2012;13(1):26-35.

7. Barros VFR. Roda do cuidar com os velhos. Revista Portal de Divulgação. 2017;(54):50-56. 